\title{
A POTÊNCIA DO SILÊNCIO NA ESCRITA DE CLARICE LISPECTOR: A NEGAÇÃO DA PALAVRA E O DRAMA DA ALTERIDADE
}

\author{
Cristiane Côrtes \\ E a solidão das pessoas \\ nestas capitais. \\ (Alucinação - Belchior)
}

RESUMO: O presente artigo pretende refletir sobre as questões relativas ao uso da linguagem na obra da escritora brasileira Clarice Lispector na perspectiva do silêncio e do silenciamento. Para nós, a escritora procura problematizar aquilo que Benedito Nunes considera ser um drama da linguagem, pois, em sua obra, sempre nos apresenta um conflito entre o que se pretende narrar e a impossibilidade de se usar palavras para esse exercício. A autora procura traduzir esse drama a partir das lacunas de representação que seu texto traduz na forma de silêncio e poesia. $\mathrm{O}$ artigo pretende desdobrar tal drama em dois aspectos, sendo o primeiro, a incapacidade de representação pela escrita, que jamais deve ser fechada ou elaborada e sim espontânea, performática. O segundo diz respeito ao exercício de alteridade denunciando a impossibilidade de a palavra literária representar a experiência alheia. Para tanto, o último romance publicado em vida, $A$ hora da estrela, será o texto usado como referência de análise, uma vez que carrega abertamente a temática da representação na figura de um narrador personagem, homem letrado, que tenta, em vão, traduzir a experiência da pobre nordestina nas ruas do Rio de Janeiro.

PALAVRAS-CHAVE: Alteridade, linguagem, silêncio.

Clarice Lispector inaugura sua escrita ainda na primeira metade do século XX, em meio à conturbação das guerras mundiais, num mundo que ainda se recuperava dos traumas vividos pela catástrofe. Contemporânea do romance regionalista, leitora de Dostoievski e Sartre, ao lado de Guimarães Rosa, Lispector inaugura uma nova perspectiva da linguagem na prosa literária brasileira. A obsessão pela palavra poética e o desejo por descortinar o funcionamento das relações humanas por meio da literatura torna a obra da autora única. Quanto a isso, Luiz Carlos Lopes (2013) afirma que a aproximação do mundo ficcional de Clarice se faz por um gesto de leitura leve, descompromissado, ou, ainda, distraído, mas que também" obedece a determinadas forças que atribuem uma recomendação que se faz pelo movimento puro e pelos deslocamentos contínuos" (LOPES, 2013, p. 12). Para o crítico, "ler Clarice significa entrar numa zona intempestiva em que o ar falta e o chão escapa, sendo ainda um lugar onde se pronuncia um Sim silencioso que está no centro de toda a tempestade.” (LOPES, 2013, p. 12). A fusão entre o poético filosófico e o inusitado proporciona uma experiência peculiar da leitura clariceana.

A hora da estrela é talvez o livro mais instigante de Lispector. A história da datilógrafa alagoana Macabéa, que migra para o Rio de Janeiro conta com um narrador-personagem que

\footnotetext{
* Doutora em Letras pela Universidade Federal de Minas Gerais (UFMG). Professor do Centro Federal de Educação Tecnológica de Minas Gerais (Cefet-MG). Pesquisadora do Núcleo de Estudos Interdisciplinares da Alteridade (NEIA-UFMG) e do Núcleo Mulheres em Letras (UFMG).
} 
se encarrega de contar toda a parca rotina da nordestina. O escritor fictício chamado Rodrigo S.M. mistura-se à trama ao elaborar sua narrativa dentro do que Lopes considera "deslocamentos contínuos" que tiram o leitor de sua zona de conforto. O drama instaurado por este narrador diante de sua personagem foi o elemento definitivo para escolhermos o referido romance como forma de aprofundar na concepção de silêncio e alteridade da narrativa de Lispector. Lançado em 1977, o romance, na figura do personagem-narrador, Rodrigo S.M., traz como pano de fundo a tensão de uma alteridade que parte de reflexões biográficas para desnudar o outro e vice-versa. O trecho "Esse eu que é vós, pois não aguento ser apenas mim, preciso dos outros para me manter de pé, tão tonto que sou eu enviesado" (LISPECTOR, 1999, p. 19) carrega, por exemplo, uma reflexão sobre essa tensão entre o pessoal e o coletivo que está no centro da tempestade a que Lopes se refere.

A autora reflete na sua escrita nossa incapacidade de lidar com a existência, com as relações e as convenções, expões a fragilidade humana que é performaticamente desdobrada nas sensações que sua leitura provoca. Regina Pontieri (1999) endossa essa afirmação quando analisa uma complexa relação entre parte e todo no conjunto da obra clariceana. Para a pesquisadora, "Clarice credita a inexistência ou fragilidade de seus enredos à sua própria natureza fragmentária: "Eu não tenho enredo. Sou inopinadamente fragmentária. Sou aos poucos" (PONTIERI, 1999, p. 115). Em sintonia com o existencialismo francês, por refletir a natureza do fragmento sendo resto de individualidade e individual ao mesmo tempo, seus textos guardam na sua própria composição a incompletude humana. Essa incompletude dialoga com o que consideramos aqui uma poética do silêncio em que não se deseja refletir a obra acabada, mas o processo e as armadilhas que a linguagem pode suscitar. Benedito Nunes, ao se debruçar sobre o drama da linguagem em Lispector, reconhece sua paradoxal busca por traduzir a concepção de mundo em escrita. Para ele, o texto de Lispector carrega uma ideia de que "as palavras amortalham os sentimentos que elas próprias partejam. O dizer modifica o sentir" (NUNES, 1989, p. 103). O crítico percebe na palavra literária de Clarice o poder imenso de traduzir o mundo e o de criar um obstáculo para essa tradução: "À sua liberdade, um muro que aprisiona" (NUNES, 1989, p. 112). É importante notarmos como esse sentimento de clausura diante do único recurso que resta para dizer do mundo em que habita é crucial para a elaboração de um projeto estético que abarca a incapacidade de tradução da palavra literária preenchida pelo silêncio.

Uma análise mesmo que en passant facilmente revela a dificuldade que as personagens clariceanas apresentam ao se comunicar. Essa dificuldade possui dimensões diferentes que 
variam desde a tagarelice despropositada até a mudez nauseabunda. Quanto ao desdobramento desse projeto, Nunes, ao analisar $A$ maçã no escuro, ainda considera que [...]

\begin{abstract}
essa ambição desmedida de equiparação entre ser e dizer expõe as personagens ao fracasso e ao desastre. Martim fracassa regressando à linguagem comum, alienada, em que as palavras se separam da realidade; G.H. fracassa separando-se da linguagem comum pela realidade silenciosa que nenhuma palavra exprime. A paixão da linguagem terá seu reverso na desconfiança da palavra, e o empenho ao dizer expressivo, que alimenta essa paixão, transformar-se-á numa silenciosa adesão às próprias coisas. (NUNES, 1989, p. 112)
\end{abstract}

Percebemos, então, duas tendências interligadas a essa frustração da incomunicabilidade ou incapacidade das palavras de atingirem o seu objetivo que seria a tradução da existência, não só humana, das coisas, bichos etc. O entrelaçamento entre fala e silêncio aparece quase como uma solução para essa desconfiança na palavra. Ao perceber a dificuldade de tradução do sentimento em palavras, comumente, suas personagens ora caem no automatismo linguístico cujo vazio se transforma em alienação ora caem no silêncio indiferente. Em Água viva, a primeira tendência está mais evidente:

Ouve-me, então com teu corpo inteiro. Quando vieres a me ler perguntarás por que não me restrinjo à pintura e às minhas exposições, já que escrevo tosco e sem ordem. É que agora sinto necessidade de palavras - e é novo para mim o que escrevo porque minha verdadeira palavra foi até agora intocada. A palavra é a minha quarta dimensão. (LISPECTOR, 1998a, p. 10)

As palavras são necessárias e a escrita acaba por traduzir o conflito entre a necessidade de dizer e a dificuldade de o fazer por palavras o que é de fato sentido ou imaginado. Há um fosso entre o que a autora imagina da vida e o que as palavras dão conta de traduzir, por isso, a verdadeira palavra estaria na quarta dimensão, ultrapassa a realidade, transcende a escrita corriqueira e funcional. Clarice insiste na trama desordenada como performance da sua leitura de mundo, "a harmonia secreta da desarmonia" (LISPECTOR, 1998a, p. 12).

A ideia de linguagem como gesto, delineada pelo filósofo italiano Giorgio Agamben (2008), é uma maneira de entender essa quarta dimensão à que se refere Lispector. Ela nega sua finalidade operacional se desvinculando da ideia de instrumento e se aproximando da pura expressão, é capaz de restituir a potência do pensamento quase sem barreiras e traduzir em partes o desejo do autor em usar as palavras ou o silêncio delas para se expressar, como a autora em questão diz, o que deseja não é

[...] o que está feito, mas o que tortuosamente ainda se faz. Minhas desequilibradas palavras são o luxo de meu silêncio. Escrevo por acrobáticas e aéreas piruetas escrevo por profundamente querer falar. Embora escrever só esteja dando a medida do silêncio. (LISPECTOR, 1998a, p. 12) 
Isso significa que, diante do desejo de fala como expressão ou representação, há uma tentativa frustrada que leva à premissa de que o silêncio está presente como resto, no que se refere à diferença entre o uso da linguagem e aquilo que ela representa. Essa dimensão do silêncio está relacionada à impossibilidade de representação que a fala carrega. A autora nos indica, performaticamente, que as palavras não podem alcançar a exata verdade do ser que ela quer representar. A escrita caótica e fragmentada seria a saída para essa circunstância, pois representa essa falha do discurso. Voltamos à ideia do ensaio para compreender melhor essa opção pela realidade silenciosa, que reflete na escrita clariceana.

Ao assumir que escreve pelo desejo profundo da fala, a autora reconhece a importância da expressão e da representação na arte. O fato é que, por mais que tente, as palavras não chegarão à dimensão daquilo que precisa ser dito, resta o silêncio. Essa escrita revela a inexatidão ou artificialidade do discurso, da palavra elaborada. Por isso é um gesto, pelo caráter ensaístico, por traduzir o silêncio que denuncia a impossibilidade de representação.

O filósofo judeu acredita que a voz como gesto esteja em um não lugar, entre o som emitido pelos animais e a voz humana. Agamben busca em Walter Benjamin o conceito de linguagem dos nomes para propor a negatividade da palavra como instrumento e aproximála do gesto. A palavra seria, assim, o gesto originário, o que não tem qualquer objeto específico que deva expressar ou nada para dizer além do que está dito na linguagem, senão a expressão dela própria (AGAMBEN, 2005, p. 309). Em Água Viva é possível encontrar esse exemplo quando a narradora afirma

\footnotetext{
Não sei sobre o que estou escrevendo: sou obscura para mim mesma. [...] Não é um recado de ideias que transmito e sim uma instintiva volúpia daquilo que está escondido na natureza e adivinho. E esta é uma festa de palavras. Escrevo em signos que são mais um gesto que voz. [...] Assim como me lanço no traço do desenho, este é um exercício de vida sem planejamento. O mundo não tem ordem visível e eu só tenho a ordem da respiração. Deixo-me acontecer. (LISPECTOR, 1998 a, p. 22)
}

Aqui está clara a opção da autora por uma linguagem que performatiza o sujeito da escrita e não tem nenhuma pretensão de comunicar, é mais visceral e primitiva, conectada com o ser que deseja apenas experimentar a linguagem como gesto originário. A palavra literária é associada na narrativa a um traço, um desenho que institivamente dialoga com a intuição ou instinto, não deseja dar um recado ou colocar em ordem os pensamentos. A relação do trecho com o que Agamben chama de gesto está principalmente nesse ato performático que acontece no momento em que se inscreve no papel uma natureza que não pode ser medida por palavras e não tem essa pretensão. Ela acontece, não se planeja ou ordena. 
O que deve ser levado em conta aqui não seria uma meta de caráter instrumental, como a transmissão de uma informação, por exemplo, mas o lúdico em uma relação ontologicamente anterior à dicotomia sujeito-objeto. Essa dimensão restitui a potência ao pensamento, é uma maneira de lhe dar vazão num fluxo de palavras caóticas, como se no inconsciente morasse o sentido das coisas e, sendo a palavra um último recurso acessível, fosse preciso tirar dela qualquer utilidade para que dela só restasse a expressão do ser ou o silêncio que ela própria revela:

Entende-me: escrevo-te uma onomatopeia, convulsão da linguagem. Transmitote não uma história, mas apenas palavras que vivem do som. Digo-te assim: -Tronco luxurioso. E banho-me nele. Ele está ligado à raiz que penetra em nós na terra. Tudo o que escrevo é tenso. Uso palavras soltas que são em si mesmas um dardo livre: - selvagens, bárbaros, nobres decadentes e marginais. Isto te diz alguma coisa? A mim fala. Mas a palavra mais importante da língua tem uma única letra: é. É. (LISPECTOR, 1998a, p. 26)

Aqui percebemos o gesto em uma espécie de convulsão de palavras. Notamos o quanto a autora se aventura pelas acrobacias que ousa fazer com seu discurso que é solto embora tenha uma profunda raiz ligada à terra, que evidencia o ser, pois privilegia a solidão da sua conjugação no presente do indicativo: "É". O isolamento da palavra é a medida do silêncio que chamamos de potência, uma vez que revela algo presente no ser que a arte não pode captar com as palavras. O narrador-personagem de $A$ bora da estrela também reflete sobre a essência do ser ao se explicar diante do leitor sobre a perspectiva de sua obra e a pobreza de sua escrita que não há nada a revelar a não ser o delicado essencial, ligado à incompletude, à falta que a escrita poderia suprir, mas o distanciamento entre palavra e essência não o permite, embora atenue.

Pensando nessa incompletude, a tese de Juliana Leal é particularmente interessante, pois credita a Lispector uma possibilidade da narrativa ser performática, pois a experiência se faz na própria narração; a linguagem carrega os aspectos dessa vivência sem o pudor do discurso elaborado exatamente por querer fazer do texto um corpo-denúncia das fraturas vividas, no caso de Macabéa ou outras personagens em que o conflito dramático se instaura sobre a pobreza ou outras fragilidades. Para a pesquisadora, há uma lógica textual acolhedora do outro como potência discursiva e vivencial que mina as possibilidades de representação ou exemplificação da narração tradicional, porque abandona a perspectiva da previsibilidade e se torna via de acesso “a domínios imprevisíveis da existência humana” (LEAL, 2012, p. 62-63). Ocorre, assim, uma transgressão da linguagem que se elabora na imagem fraturada como a dos sujeitos pós-guerra que convivem com o vazio e não entram no processo de tamponamento aleatório, como a tagarelice. 
As palavras são, nessa perspectiva, o reflexo da alma, e não da consciência, por isso transgridem a lógica cartesiana, tornam-se palavras soltas, onomatopeias, convulsão, gesto. Essa convivência com o vazio dialoga com a ideia de silêncio relacionada com o que resta, a predominância do espaço vazio no corpo do texto é uma transgressão e a persistência do silêncio é a denúncia da opressão sofrida tanto pela dor quanto pela barbárie. A transgressão da linguagem é um recurso que performatiza o drama da autora em relação às palavras, pois, ao contrário de expressar o pensamento, deve traduzir a incompletude humana, evidencia a dificuldade de acessar o delicado essencial. A falha nas tentativas de entender a vida por meio do discurso reflete-se na linguagem do gesto que abandona seu status de ferramenta para se ver a serviço da alma, no fluxo de consciência, intimismo e experiência. Nunes, ao discorrer sobre $A$ paixão segundo G.H. e $A$ hora da estrela, em relação ao fracasso da linguagem como ferramenta de representação do conflito humano, afirma estarem, as obras, num espaço literário agônico em que a ficção meditativa, feita de súbitas iluminações, produz um movimento dubitativo de uma escrita errante, como que impelida pelo vago objeto de desejo, num gesto de improviso, porque, "tal como o impromptu musical, a escritura se desenrola ao léu de múltiplos temas e motivos recorrentes (autoconhecimento, expressão, existência, liberdade)" (NUNES, 1989, p. 169).

Essa escritura é percebida no discurso elaborado e metalinguístico de Rodrigo e na mudez de sua protagonista. A narrativa está centrada nesta consciência conflituosa diante da urgência e calamidade pública na qual o desejo da alteridade se confunde com o falar pelo outro e ratifica o silenciamento que promove a ausência do sujeito enquanto tal. A trama nos revela um narrador que vive o dilema de precisar fazer um romance social e não encontrar a maneira ideal de colocar em palavras toda a pobreza de sua protagonista. Aqui vale ressaltar a crítica que a autora faz ao romance social da década de 30 que trazia para a cena o pobre nordestino subalternizado nesse exercício de alteridade, contudo, o próprio romance revela essa impossibilidade, seja pelo distanciamento entre o narrador e seu objeto, do ponto de vista social e econômico, principalmente, seja pela incomunicabilidade da palavra literária, que torna qualquer tentativa de revelar algo sobre a vida artificial, como estamos desenhando neste artigo.

O crítico francês Maurice Blanchot, ao descrever sobre o espaço literário, diz que a obra é o lugar onde o autor, enquanto escreve, "expõe-se perigosamente à pressão que exige que ele escreva, mas também se protege dela" (BLANCHOT, 1987, p. 46). Para ele, o autor se protege do mundo criando uma ficção em que reine soberanamente e isso vai protegê-lo e aprisioná-lo. O caráter metaficcional do romance clariceano evidencia essa relação do autor 
com sua obra, pois ele menciona tanto a necessidade de escrever, como um trabalho que precisa ser cumprido, quanto o desejo de poder criar uma história a partir de suas impressões do mundo: "Por que escrevo? Antes de tudo porque captei o espírito da língua e assim às vezes a forma é que faz o conteúdo. Escrevo portanto não por causa da nordestina mas por motivo grave de 'força maior', como se diz nos requerimentos oficiais 'por força da lei"' (LISPECTOR, 1999, p. 18). O trecho manifesta a exigência da obra tanto em relação à sua poética, o espírito da língua, quanto à exigência de uma obra que fale de questões sociais, dentro do contexto histórico em que foi publicada.

A crítica especialista em Clarice Lispector, Nádia Gotlib (2001) nos lembra que o tema escolhido pelo narrador-personagem não é a nordestina, como insiste em dissimular, mas os dilemas de um autor diante de seu objeto para a construção de um romance. Mais uma vez, é o drama da linguagem que se instaura. O narrador descreve sobre a necessidade de falar sobre a mulher na condição de subalternidade como se essa fosse uma maneira de conseguir lidar com a pobreza, uma missão que cabe ao intelectual burguês, como dito acima. Mas há também, como o crítico francês aborda, uma proteção ao estampar a miséria na escrita, pois, falar da pobreza é uma forma de lidar com ela sem precisar tocá-la. Os conflitos apresentados pelas narrativas no tocante à alteridade passam pelo que Blanchot chama de "riscos da experiência", pois o autor não se sente livre no mundo, mas privado dele, "exposto a uma exigência que, ao repeti-lo para fora da vida e de toda a vida, torna-o vulnerável a esse momento em que nada pode fazer e já não é ele próprio" (BLANCHOT, 1987, p. 47).

Tal reflexão nos mostra o jogo de representação do espaço literário que cria um universo paralelo ao real para representar uma experiência que dialoga com a vivida, mas é outra, pois é construída a partir da linguagem literária, “onde tudo poderá ser feito; nela, o artista pode vingar-se de seus fracassos", a obra o atrai para fora do mundo e lhe impõe o silêncio, "é a fala da experiência original" (p. 47). Tocar o silêncio da obra seria o que Rodrigo S.M. considera o "delicado essencial", é sair do véu que a linguagem ordena e tocar no "oco da palavra". É esse jogo da ficção que deseja representar o real num espaço paralelo que Lispector expõe em suas obras. Ela não dissimula, nem credita em suas palavras o dom de dizer, pelo contrário, denuncia a fragilidade da representação. Para ela, a linguagem é vazia e o silêncio é o que importa. Isso se evidencia na criação de uma personagem que pouco tem a oferecer a não ser a reflexão sobre as relações de poder na sociedade.

Blanchot nos é útil na medida em que desmonta esse ideal literário revelando o conflito entre o autor e sua obra, entre o criador que é tomado pela criatura e vê refletido nela tudo o que dialoga com o mundo que vê. A vulnerabilidade dos narradores está, muitas vezes, no 
conflito entre alteridade e honestidade desde o prefácio do romance, em que a autora nos informa da escrita em estado de emergência e calamidade pública. $\mathrm{Na}$ introdução de $A$ bora da estrela, o narrador afirma "Enquanto eu tiver perguntas e não houver respostas continuarei a escrever" (p. 11) e mostra que a obra se faz a partir de questionamentos, embora a palavra não possa restabelecer seu sentimento diante do vivido: "minha vida a mais verdadeira é irreconhecível, extremamente interior e não tem uma só palavra que a signifique” (p. 11). A falta de palavras aqui nos remete ao desejo de compreender a linguagem do silêncio ou acessar a "fala da experiência original". A escrita ensaística da autora torna possível a elaboração de uma obra laboratorial em que a dor e a fragilidade do narrador são também expostas: "A dor de dentes que perpassa esta história deu uma fisgada funda em plena boca nossa. Então eu canto alto e agudo uma melodia sincopada e estridente - é a minha própria dor, eu que carrego o mundo e há falta de felicidade" (p. 11). A constante dor de dentes nos remete ao incômodo de pertencer a um mundo miserável e à impotência diante disso em conflito com o bem-estar por se encontrar em determinada e privilegiada posição, seja social, seja intelectual. O canto estridente é a própria obra que, como Blanchot reconhece, é a vingança do autor que está oprimido pelo mundo em que vive e tenta se proteger num universo criado para dar vazão a seu pensamento e sentimento: "Pensar é um ato. Sentir é um fato", afirma Rodrigo ao introduzir sua narrativa (LISPECTOR, 1999, p. 11).

Quanto à escolha da trama, buscamos em Foucault uma explicação plausível sobre o apreço pelo desamparo a que são entregues as personagens de $A$ bora da estrela. Em $O$ que é um autor (2009), o filósofo data uma mudança importante, no século XVII, na cena literária do Ocidente em que a ideia do fabuloso, ou seja, do que merecia ser dito, é substituída pelo impossível ou irrisório:

\footnotetext{
Nasce uma arte cuja tarefa já não é cantar o improvável, mas pôr em evidência o que não é evidente. [...] A partir do momento em que se instala um dispositivo para forçar dizer o ínfimo, aquilo que não se diz, que não merece glória nenhuma, o infame portanto, toma forma um novo imperativo que vai construir o que se poderia chamar a ética imanente ao discurso literário do ocidente. (FOUCAULT, 2009, p. 125)
}

Essa opção conversa também com a força gravitacional da qual Gotlib (1987) se refere ao dizer da recorrência da literatura que trata do contexto social e de uma possível arrogância nesse tratamento. Isso, segundo o filósofo, dialoga com sua dupla relação de verdade e poder, ela faz parte de um grande sistema de coação por meio do qual o "ocidente obrigou o quotidiano a pôr-se em discurso", ele adverte que "esta posição singular da literatura não é senão o efeito de um certo dispositivo de poder que atravessa, no Ocidente, a economia dos discursos e a estratégia do verdadeiro" (FOUCAULT, 2009, p. 127). A presença dos sujeitos 
e situações ordinárias, para o autor de $A$ ordem do discurso, não significa uma valorização dessas circunstâncias ou tampouco um desejo de retirar a subalternidade, por exemplo, do anonimato. Essa literatura não fabulosa cria, mormente, situações que se tornam verdade sobre os sujeitos e os lugares que ocupam no espaço social, ou, ainda, se falam, como e de onde falam. Dessa forma, o autor endossa o que estamos desenhando para caminharmos até o entendimento do silêncio da negação que performatiza a ausência ou a mudez desses sujeitos no corpo do texto. Além da elaboração de sua personagem se fazer na ausência, encontramos um narrador que tenta se apropriar dessa negação para se aproximar de seu objeto e acaba por reforçar seu estereótipo. Vários são os trechos em que Rodrigo diz ter de passar fome, ficar sem comer, sem conversar, descer à lama, para experienciar a pobreza da qual sua personagem está imersa:

Por enquanto quero andar nu ou em farrapos, quero experimentar pelo menos uma vez a falta de gosto que dizem ter a hóstia. Comer a hóstia, sentir o insosso do mundo e banhar-se no não. Isso será coragem minha, a de abandonar sentimentos antigos já confortáveis. Agora não é confortável: para falar da moça tenho que não fazer a barba durante dias e adquirir olheiras escuras por dormir pouco. Só cochilar de pura exaustão, sou um trabalhador manual. Além de vestirme com roupa velha rasgada. Tudo isso para me pôr no nível da nordestina. (LISPECTOR, 1999, p. 19, grifos nossos)

O trecho é emblemático porque toca na questão que estamos desenvolvendo aqui sobre o conflito entre o narrador e seu desejo de representar sua personagem num gesto de alteridade, o que desencadeia o chamado silêncio da negação. O narrador afirma ter de se despir de seu conforto para conseguir se aproximar de seu objeto. A precariedade e a ausência são duas constantes na narrativa, seja do ponto de vista metalinguístico - a intenção de falar sobre algo e faltar-lhe palavras ou jeito para fazê-lo - seja do ponto de vista estrutural - o narrador constrói uma personagem a partir de tudo o que lhe falta. Macabéa, para S.M., carece de tudo, ela está imersa no não. Dessa forma, o "não" passa a ser a tônica da narrativa, uma posição nada confortável.

Quando S.M. confessa ter de cumprir esse ritual do "não" para estar no nível da nordestina, desvela um aspecto de sua escrita que também estamos delineando: a arrogância do intelectual burguês que acredita ter uma única lente capaz de compreender o mundo. Em sua conferência sobre “O que é um autor", Foucault (2009) facilita nossa compreensão, pois ele define a imagem do autor como um nome próprio que corre aos limites do texto e está atrelada ao modo de existência, circulação e funcionamento de certos discursos presentes na sociedade. O nome do autor é "mais que uma indicação, um gesto, um dedo apontado para alguém” (p. 42). Esse nome seria a composição de um discurso que elabora uma pessoa, com suas especificidades, e envolto em uma mítica, uma aura que lhe concede voz e veracidade. 
Está aí, a nosso ver, a maior relevância na escolha da autora Clarice Lispector ao criar um autor Rodrigo S.M. para falar de Macabéa. Ele é a evidência do distanciamento entre o nome do autor e o objeto frágil, feminino e pobre que é sua personagem. Uma autora falaria sob outra ótica, e o projeto de performatizar o poder da palavra e evidenciar a potência do silêncio não seria efetivo; uma autora não precisaria compor uma cena para estar no nível de sua personagem (grifo nosso).

O que conhecemos de Macabéa passa, sem dúvida, pelo crivo de seu narrador, sendo assim, a contradição não poderia deixar de ser inerente à sua constituição. Para Nádia Gotlib, a nordestina tinha uma ingenuidade inofensiva e indefesa que "causa consternação enternecida, por parte do narrador - e do leitor. Porque apesar de toda a sua pobreza, ou miséria, "não havia nela miséria humana. É que tinha em si mesma uma certa flor fresca"" (GOTLIB, 2001, p. 308-309). O narrador tenta despertar em sua personagem o direito ao grito, deseja ver nela a reivindicação por uma vida mais justa, mas era flor fresca, tinha o delicado essencial, e revolta era sentimento que desconhecia. O narrador ambiciona desestabilizar sua personagem como se a narrativa pudesse ser uma via de mão dupla. A contradição instaurada na trama, portanto, parte das reflexões de S.M., e Macabéa continua ilesa na sua simplicidade.

Sobre essa relação entre criador e criatura, a Pequena Flor do conto "A menor mulher do mundo" se aproxima muito de Macabéa. Encontrada por um importante pesquisador nas profundezas da África equatorial, "uma mulher de quarenta e cinco centímetros, madura, negra, calada" (LISPECTOR, 1998a, p. 97) vira atração no suplemento do jornal de domingo em que apareceu em tamanho natural. O conto tem a mesma riqueza do romance e de muitas crônicas no que tange à honestidade em relação ao egoísmo disfarçado de alteridade. A narração quase jornalística desvela a conexão do pesquisador diante de seu objeto de pesquisa, bem como das pessoas que viam a foto daquela raridade direcionando o leitor para uma crescente indignação sobre o direito que as pessoas acreditam ter sobre a foto ou a frágil africana. As reações diante da miniatura foram surpreendentes:

num apartamento, uma mulher, ao olhar no jornal aberto o retrato de Pequena Flor, não quis olhar uma segunda vez 'porque me dá aflição. [...] Em outra casa, na sagração da primavera, a moça noiva teve um êxtase de piedade: — Mamãe, olhe o retratinho dela, coitadinha! olhe só como ela é tristinha! (p. 100-101)

Aflição, deboche, piedade são os sentimentos mais comuns despertados pela pequena mulher.

Em outra casa, junto a uma parede, deram-se ao trabalho alvoroçado de calcular com fita métrica os quarenta e cinco centímetros de Pequena Flor. [...] No coração de cada membro da família nasceu, nostálgico, o desejo de ter para si aquela coisa 
miúda e indomável, aquela coisa salva de ser comida, aquela fonte permanente de caridade.

$[\ldots]$

- Deve ser o bebê preto menor do mundo — respondeu a mãe, derretendo-se de gosto. - Imagine só ela servindo a mesa aqui em casa! e de barriguinha grande! (LISPECTOR, 1998a, p. 104)

A constatação sobre a inerente crueldade humana inaugura uma série de reflexões no conto que dialogam com uma honestidade clariceana ao reconhecer ser impossível o exercício da alteridade. A necessidade de ter aquele "objeto misterioso" para si fez o explorador se julgar no direito de examinar, apalpar e publicizar sua descoberta. Macabéa, assim como Pequena Flor, é a evidência da fragilidade diante do explorador que se julga no direito de sobre o outro. O clímax do conto revela a instabilidade do explorador diante das risadas de sua descoberta:

Metodicamente o explorador examinou com o olhar a barriguinha do menor ser humano maduro. Foi neste instante que o explorador, pela primeira vez desde que a conhecera, em vez de sentir curiosidade ou exaltação ou vitória ou espírito científico, o explorador sentiu mal-estar. É que a menor mulher do mundo estava rindo. [...] A própria coisa rara estava tendo a inefável sensação de ainda não ter sido comida. (LISPECTOR, 1998a, p. 105-106)

Devemos ressaltar a descrição dos sentimentos comuns ao explorador em relação à descoberta que foram rompidos com a risada. Não sentira nada que pudesse ratificar sua grandeza e inteligência, pelo contrário, o riso incomoda. O explorador "perturbou-se como só homem de tamanho grande se perturba" (p. 112) denunciando a instabilidade que a pequena mulher pode causar em um "importante" homem, como o silencia de Maca faz com S.M.. A risada da africana é o essencial delicado a que S.M. tanto persegue, é a capacidade de se entregar ao momento e se permitir ter um simples prazer. O diálogo entre Macabéa e Pequena Flor é tão estreito que podemos enxergar uma na outra; o riso, assim como o silêncio, é uma espécie de resiliência que faz com que a personagem se imponha diante do outro mostrando que ali há mais que um simples objeto. Apesar de serem tratadas como criaturas presas num laboratório, em constante observação, vítimas de intelectuais ou cientistas obcecados por seus métodos, tanto o contentamento quanto o mutismo vão desestabilizar a figura desse intelectual que só consegue ver a si próprio.

É possível perceber um gesto transgressor que as narrativas instauram a partir do jogo silêncio/silenciamento uma vez que oscilam entre a mudez e a instabilidade do intelectual diante de um cenário que ele próprio criou. Embora haja toda uma narrativa contra essas protagonistas, conseguimos perceber nas entrelinhas de seus parcos gestos uma perspicácia diante da vida descrita pela simplicidade e felicidade que compõem sua personalidade. Macabéa tem como estratégia de sobrevivência se entregar aos pequenos prazeres de forma 
grandiosa, o que causa constante incômodo no narrador, uma vez que ela vivia muito bem com a vida de negação que seu narrador lhe impôs.

Macabéa é a evidência do inefável, a personificação da contradição em que a repulsa pela pobreza e o desejo de exercitar a alteridade entram em conflito. Para Gotlib, esta, como outras personagens da ficção de Clarice, integra-se a um circuito de mulheres-personagens "desestabilizadoras da ordem e instauradoras de questionamentos pela própria palavra, num bombardeio da linguagem que inaugura uma nova postura diante do processo do sentido e da significação" (2001, p. 310). É essa faculdade desestabilizadora de Maca que chamamos de transgressão da narrativa, pois seu silêncio um duplo viés na obra. Se pensarmos no processo de silenciamento presente na obra - decorrente da relação de subalternidade estabelecida pelo narrador em que só há uma voz para representar todas as partes - a mudez da protagonista é uma resposta a toda negação a que foi submetida como uma moeda de troca pela austeridade de seu criador.

O silêncio da nordestina deixa Rodrigo sem material para conclusão de seu trabalho, o que transforma a narrativa em uma tensa agonia. A evidência dessa afirmação está nas declarações do narrador-personagem; não raras, elas atestam o incômodo que o silêncio causa no narrador e comprovam a faculdade desestabilizadora a que Gotlib se refere ao caracterizar as mulheres-personagens de Lispector. Se agruparmos essas declarações, teríamos a ideia do silêncio associado ao mistério ou ao desconhecido: "essa história será o resultado de uma visão gradual" (p. 12); "História exterior e explícita, sim, mas que contém segredos" (p. 13); “o material de que disponho é parco e singelo demais, as informações sobre os personagens são poucas e não muito elucidativas, informações essas que penosamente vem de mim para mim mesmo, é trabalho de carpintaria" (p. 14); "Juro que este livro é feito sem palavras. É uma fotografia muda. Este livro é um silêncio" (p. 17); “Tenho que tornar nítido o que está apagado e o que mal vejo" (p. 19); "Sei de muita coisa que não posso dizer" (p. 69); "Qual foi a verdade de minha Maca? Basta descobrir a verdade que ela já não é mais: passou o momento. Pergunto: o que é? Resposta: Não é” (p. 85). Os trechos indicam o objeto inefável do qual Rodrigo tenta se apoderar.

A ideia de distanciamento/aproximação do objeto acompanha uma crescente que começa confessando a dificuldade desse narrador em chegar até a personagem muda e gradualmente a enxerga e percebe que ali só há silêncio, até chegar à iminência da morte, à constatação de que a personagem não é o que creditou seu criador. A pulsão de vida, o desejo burguês de vê-la mudar se esvazia diante da impossibilidade de realização de seus sonhos. A verdadeira história sobre Macabéa é a perspectiva de Rodrigo - "verdade de minha Maca" - 
, que insiste em se aproximar, contudo se distancia. Rodrigo consegue ver apenas a história da negação que criou para sua personagem. Esse silêncio que paira sobre a ausência da alteridade, mesmo quando se deseja tanto, mas parte da perspectiva errada para alcançar o que considera objeto, é a falta de interlocução entre o criador e a criatura, é a evidência da solidão em que estão imersas essas pessoas. Rodrigo, por não ter o que falar de Macabéa, está sempre voltado para seu próprio ego, seus métodos, suas reflexões sobre seu objeto, e não percebe na tagarelice erudita a distância abismal que o separa da doce Maca, a ausência de sua alteridade. Nádia Gotlib toca nesse vazio relacionado à problemática da representação que coloca em xeque a palavra literária, o que acaba por se tornar também a conclusão de Rodrigo:

O autor implícito parece se servir de todas as artes e de todas as vozes para querer preencher a falta que sua Macabéa lhe faz sentir. Mas todo o esforço é inútil. O arsenal das representações lhe deixa apenas a constatação de que tudo isso nada vale a não ser como moeda que se contesta e que se destrói, para, mediante o uso desse repertório, destruir sua própria eficácia de representação, num processo suicida da palavra - e da arte em geral. A palavra só vale quando dela não se precisa mais, atingindo o sentido pleno na nudez do silêncio. (GOTLIB, 2001, p. 312)

A figuração da palavra suicida é a constatação de Rodrigo que afirma "Macabéa me matou"; a morte, como o silêncio, é a liberdade das amarras da representação - "Ela estava enfim livre de si e de nós" -, ela se liberta de seus estereótipos e o narrador descobre que não há como representar o doce e inefável, o silêncio "que nem o pensamento pensa" (LISPECTOR, 1999, p. 86).

Ainda na perspectiva de agruparmos as sensações de S.M. diante do silêncio da nordestina, uma segunda coleção de frases nos mostra o silêncio como resposta ao grupo anterior. Se por um lado o narrador só vê água rala em sua personagem, por outro, essa plenitude silenciosa de Maca desencadeia um sofrimento em seu criador como uma vingança ou um ato de resistência diante da negação imposta: “O que escrevo é mais que invenção, é minha obrigação contar sobre essa moça entre milhares delas" (p. 13); "Tentarei tirar ouro de carvão. Sei que estou adiando a história e brinco de bola sem a bola" (p. 16); "é que realmente não sei o que me espera, tenho um personagem buliçoso nas mãos e que me escapa a cada instante querendo que eu o recupere" (p. 22); "Ela me incomoda tanto que fiquei oco. Estou oco desta moça e ela tanto mais me incomoda quanto menos reclama. Estou com raiva. [...] Como me vingar?” (p. 26); “É assim que se escreve? Não, não é acumulando e sim desnudando. Mas tenho tanto medo da nudez, pois ela é a palavra final” (p. 82). Os trechos aqui em sequência também constroem uma perspectiva crescente, pois partem da ideia de escrever por obrigação, já discutida na seção anterior, relacionada à questão da pobreza. Porém essa concepção de pobreza se reverte na própria reflexão sobre a obra que está sendo escrita. O 
narrador começa a perceber que a opacidade de sua personagem é, na verdade, sua dificuldade de lidar com o objeto que julgava ser dono e com o vazio da própria vida. A impaciência diante de Macabéa, a visão turva ou a mudez deixam S.M. num completo vazio diante de sua musa que não o inspira, o medo da nudez é a constatação de que o silêncio é mais poderoso que as palavras vazias de representação. O silêncio de Macabéa desatina seu narrador e repercute nessa representação agônica de uma realidade da qual desconhece.

Há poucos diálogos em que Macabéa aparece numa outra perspectiva e com certa sagacidade, como se escapasse à narrativa totalizante certos momentos da sua vida: "Ela era de leve como uma idiota, só que não o era" (LISPECTOR, 1999, p. 26). O próprio silêncio da nordestina confunde aqueles que a cercam, ratificando as considerações de Eni Orlandi (1997) sobre a relação entre o opressor e o oprimido em que o silêncio é uma forma de tirar do algoz a capacidade de controlar sua vítima. Voltemos aqui a pensar em Macabéa dentro desse circuito de mulheres-personagens que incomodam. Os diálogos com o namorado Olímpico de Jesus evidenciam essa faculdade mais claramente. Ao explicar a origem de seu nome ao pretendente que diz ser esse um nome de doença, a nordestina concorda e afirma o quanto é esquisito mesmo, mas cumpre uma promessa feita pela mãe à Nossa Senhora da Boa Morte devido aos problemas de saúde na infância. Macabéa explica que até um ano de vida não era chamada porque não tinha nome e preferiria que ainda fosse assim: "continuar a nunca ser chamada" (p. 43). Assim, ao perguntar o nome do acompanhante, indaga surpresa:

Eu não entendo o seu nome, disse ela. Olímpico? [...] Mesmo ele, galinho de briga que era arrepiou-se todo com a pergunta tola que ele não sabia responder. Disse aborrecido:

— Eu sei mas não quero dizer!

— Não faz mal, não faz mal, não faz mal... a gente não precisa entender o nome. (LISPECTOR, 1999, p. 44)

O trecho exibe uma Macabéa mais consciente do que o habitual. Sua relação com o nome, mesmo desgostosa, vai situá-la diante da vida, inclusive a ponto de desejar não ser chamada, o que lhe permite alguma leveza ou conveniente invisibilidade. Ao questionar sobre a origem de seu nome, Olímpico, que era aparentemente um sertanejo forte e determinado, tem a sua existência colocada à prova. Desestabilizado diante da pergunta, tem a piedade da futura namorada, que afirma ser natural não entender o nome. Essa é outra postura interessante, porque Olímpico afirma que sabe e não quer dizer o significado, mas Macabéa de pronto compreende que o homem mente envergonhado. Aqui há uma certa vingança à arrogância do nordestino, que primeiramente ridiculariza o nome da possível namorada. 
Há outro momento, após um longo e cômico diálogo, no qual Olímpico diz que Macabéa é impossível. Isso porque a conversa com o namorado é vazia e ela acaba por exigir uma explicação mais profunda, o que é impossível para um homem tão arrogante. Ele fica visivelmente irritado: “Olhe, você não reparou até agora, não desconfiou que tudo que você pergunta não tem resposta?” (p. 49). A dificuldade de lidar com o desconhecido gera em Olímpico desprezo pela namorada, ele a ofende, devolve para ela seu incômodo diante da situação de escassez que também pertence a ele, embora negue peremptoriamente. A discussão sobre a riqueza ratifica essa assertiva:

Quando ele falava em ficar rico, uma vez ela lhe disse:

— Não será somente visão?

— Vá para o inferno. Você só sabe desconfiar. Eu só não digo palavrões porque você é moça-donzela.

— Cuidado com suas preocupações, dizem que dá ferida no estômago.

- Preocupações coisa nenhuma, pois eu sei no certo que vou vencer. Bem, e você tem preocupações?

- Não. Não tenho nenhuma. Acho que não preciso vencer na vida.

(LISPECTOR, 1999, p. 49)

A transcrição nos coloca diante de uma Macabéa diferente daquela apresentada por Rodrigo. Ao duvidar da possibilidade de enriquecimento do companheiro, Maca o desnuda e ainda alega não sofrer com essa ambição, pois não precisa vencer na vida. A escolha do verbo é crucial para o entendimento da cena - não precisa vencer - diferente de não quer ou não pode. A mulher demonstra arrogância diante da intenção infantil do namorado. Esses lampejos de Macabéa nos fornecem matéria para questionar parte do discurso do narrador, que a vê frágil e miserável. A nordestina torna-se insuportável para Olímpico, assim como para Rodrigo. Ao se despedir da namorada, o sertanejo a chama de cabelo na sopa, "não dá vontade de comer" (p. 60), e essa expressão nos permite duas interpretações. Uma, a usual, indica a ausência de beleza ou algum atributo que possa despertar desejo no homem, porém, o próprio narrador, linhas abaixo da declaração de Olímpico fala de certa sensualidade da protagonista; a outra está ligada ao fato de Maca ser indigesta, difícil de processar. A assertiva descarta a primeira hipótese de análise do trecho, restando-nos uma avaliação mais profunda que dialoga com nossa ideia de uma mulher-personagem inquietante. Macabéa é intragável porque evidencia um lado obscuro e silencioso negado no outro. Sua honestidade é o cabelo na sopa, pois, embora cause repulsa, está evidente.

O diálogo com Glória encerra essa coletânea de vozes que vão de encontro à Macabéa criada por Rodrigo. A protagonista pinta os lábios com um batom vermelho e Glória se espanta diante da imagem confusa:

— Me desculpe eu perguntar: ser feia dói? 
— Nunca pensei nisso, acho que dói um pouquinho. Mas eu lhe pergunto se você que é feia sente dor.

— Eu não sou feia!!!, gritou Glória.

(LISPECTOR, 1999, p. 62)

Mais uma vez, a protagonista continua plena diante de um gatilho de instabilidade. Observemos que Maca não nega a possibilidade de ser feia, pelo contrário, ela lida com a situação com naturalidade e coloca Glória no mesmo patamar afirmando, e não perguntando, se a colega é feia. Macabéa devolve a pergunta já partindo do princípio de Glória não é bonita, mesmo recurso utilizado ao dizer que Olímpico está se iludindo ao afirmar que será rico. A nordestina provoca a carioca assim como fez com o namorado, a partir do que lhes é mais caro, a vaidade; seja pela ambição cega, seja pela futilidade ilusória.

Se pensarmos nesse conjunto de falas, encontraremos uma Macabéa mais coerente com o significado de seu nome, o povo Macabeu, descendente de Judas Macabeu, líder judeu que se revoltou contra o domínio grego-macedônico e libertou o país da humilhante invasão estrangeira, é reconhecido pela capacidade de resistir e se impor diante das atrocidades: um povo resiliente, poderíamos afirmar. Embora haja toda uma narrativa na contramão do que estamos construindo, podemos reconhecê-la como "pertencente a uma resistente raça anã teimosa que um dia vai reivindicar o direito ao grito" (LISPECTOR, 1999, p. 80). Essas falas soam como "assovio no vento escuro" que desmontam uma personagem diante de seu silêncio e nos abre precedente para encontrar um relampejo de uma outra possível Macabéa.

A maneira como o silêncio se configura na trama elaborada de Clarice Lispector nos incita a pensá-lo sob dois aspectos: há um silêncio imposto pela negação. Mulher em condição subalterna e muda, Macabéa não tem o que falar aos olhos de Rodrigo, não tem memória ou história nem família. A esse silenciamento, atribuímos o silêncio da negação (grifo nosso), a honestidade da autora em tratar da alteridade ou de sua incapaz manifestação. Por outro lado, enxergamos Macabéa e seu peculiar silêncio, não aquele que passa pelo crivo do estereótipo, uma mudez grávida de um grito estridente, como poderia classificar o performer americano John Cage (HELLER, 2008). O silêncio explosivo de Macabéa desequilibra seu narrador exatamente por se quedar harmonicamente. Ele se instaura diante das demais personagens como os happenings do performer americano, 4'33", por exemplo, em que um pianista sobe ao palco, toma a postura de quem vai tocar e não toca nada, deixa a plateia com seus próprios ruídos, ruminando sua angústia diante da expectativa frustrada. É o que acontece com as personagens de $A$ hora da estrela. A estabilidade da nordestina diante da simplicidade como fórmula da vida desestabiliza, desestrutura Olímpico, Glória e Rodrigo, que a veem intragável 
em seu silêncio. É a transgressão da narrativa que, num gesto antropofágico, rumina o silenciamento imposto, acolhe e o transforma.

O silenciamento de Macabéa seria a iminência da morte, anunciada desde o início do texto, "só não inicio pelo fim que justificaria o começo - como a morte parece dizer sobre a vida - porque preciso registrar os fatos antecedentes”, diz Rodrigo (p. 13). É uma representação da impossibilidade de que uma estrela como Macabéa brilhe diante dos refletores dos centros urbanos em que a linguagem da técnica e da ciência prepondera. A morte da estrela na obra traduz o pensamento de Pasolini retratado pelo filósofo DidiHuberman (2011) acerca da sobrevivência dos vaga-lumes. O cineasta, bem como S.M., não vê possibilidade de vigorar, em meio a tanta espetacularização, a simplicidade da luz de um vaga-lume. Maca, diante da possibilidade de amar, em sua simplicidade, brilha com sua luz de vaga-lume que embora não tenha muito alcance é capaz de refletir esse sentimento na escuridão. Sim, os vaga-lumes só brilham na total escuridão. Associados à cultura popular, os pequenos estão cada vez mais diluídos na clarividência das metrópoles, seus lampejos são a prova de que ainda persiste uma memória que ecoa do passado e grita, reivindicando o “direito ao grito". Fim da experiência, para Benjamin, triunfo do capitalismo, para Adorno.

A aproximação de Macabéa com os vaga-lumes nos permite conceber $A$ bora da estrela a como um apelo à necessidade de nos voltarmos para essa memória-sintoma, esse lampejo de memória que, por um instante, evidencia o passado dos escombros. O dilema que o narrador vive - "Vou fazer o possível para que ela não morra. Mas que vontade de adormecêla e de eu mesmo ir para a cama dormir" (LISPECTOR, 1999, p. 81) - manifesta o desejo de que esse risco de luz deva permanecer, mas ele sabe que sua vida é de agonia: "Capim na grande Cidade do Rio de Janeiro. À toa. Quem sabe se Macabéa já teria alguma vez sentido também que era à-toa na cidade inconquistável” (p. 81). A descrição agônica da protagonista pode ser lida também como uma performatização desse conflito entre o desejo de sobrevivência da simplicidade e a constatação de que ela não persistirá por muito tempo. A sentença de morte de Macabéa ratifica nossa concepção de silêncio lido como uma marca potente no discurso, pois a ele podemos atribuir condições de produção e contexto em que se cria, é a pausa fundamental, o poema que grita diante da barbárie. Para Lispector, o silêncio é uma forma de apalpar o invisível. Em $A$ bora da estrela, o livro-mudo lida com a invisibilidade e o desejo frustrado de torná-la aparente.

Em última instância, ratificamos a intenção deste artigo de sugerir uma reflexão sobre o silêncio coma possibilidade potência e a obra de Clarice Lispector nos indica esse caminho. Partimos do drama da linguagem clariceana para mostrar uma perspectiva ensaística que 
estaria mais próxima da representação estética do que um texto pronto, elaborado que camufla o pensamento. Insistimos nessa linguagem como gesto que honestamente assume suas fissuras, como feridas abertas, principalmente no tratamento da alteridade. A última obra publicada em vida da autora nos revela o dilema de um narrador que pouco pode falar de uma condição da qual ele não experienciou.

A questão da linguagem na obra de Lispector é, sem dúvida, um solo fértil para nós, dos estudos literários. Aqui, detivemo-nos em um aspecto, o silêncio. Ao levar para a palavra literária o conflito sobre linguagem e representação, a autora nos apresenta o grito mudo como forma poética de expressão, esse grito aparece em sua obra como um desenho, um traço que espontaneamente dialoga com o pensamento ou com a alma. O fluxo de consciência, as lacunas textuais e epifanias expressam bem o conflito que reside em representar aquilo que vai além do signo escrito.

Nessa esteira, chegamos até Rodrigo S.M. e o drama encontrado em muitas outras obras da autora, que oscila entre a necessidade de falar do outro como exercício de alteridade e a impossibilidade de fazê-lo, seja pela limitação da palavra, já descrita aqui, seja pela ausência de uma experiência que comungue com aquela narrada. O que temos é um narrador burguês letrado que nada sabe sobre uma nordestina miserável a não ser aquilo que os une, a escassez, da inspiração para um, do alimento para outro. Resta o vazio diante da personagem que passa a definida por um narrador que só enxerga aquilo que ela não tem. A essa construção narrativa a partir do que falta, do que não tem ou não é, chamamos de silêncio da negação, que seria um desdobramento do drama da linguagem que pouco pode expressar ou representar. Mesmo num exercício de alteridade, falta palavras para descrever o desconhecido.

Contudo, esse silêncio ensurdecedor de Macabéa tem a força de paralisar S.M. e mostrar para o leitor o incomodo e sofrido lugar da subalternidade e que talvez a questão seja, quando o assunto é alteridade, a falta de escuta, uma surdez social, e não a mudez. Há uma diferença substancial entre silêncio e silenciamento. Um, grávido de som, carrega a potência da reflexão; o outro, parte da arrogância de não saber ouvir e cria uma barreira apoiada na incomunicabilidade entre o "nós" e o "eles".

Ter na literatura a condição de elaborar esteticamente uma realidade oprimida é pensar num devir melhor, numa situação em que seja possível vislumbrar escapes para a opressão. Se pensarmos, como Barthes, que toda língua é fascista, o silêncio pode questionar essa arbitrariedade, ressignificar as formas de comunicar e problematizar a interferência na audição provocada pela mudez. Uma literatura silenciosa poderia ser lida como uma contra- 
narrativa que carrega uma potência de transformação diante de uma tradição literária já legitimada. Foi o que pretendemos discutir aqui, ao trazer a obra de Clarice Lispector e toda a sua tempestiva potência.

\section{EL PODER DEL SILENCIO EN LA ESCRITURA DE CLARICE LISPECTOR: LA NEGACIÓN DE LA PALABRA Y EL DRAMA DE LA ALTERIDAD}

RESUMEN: Este artículo pretende reflexionar sobre cuestiones relacionadas con el uso del lenguaje en la obra de la escritora brasileña Clarice Lispector desde la perspectiva del silencio y del silenciamiento. Para nosotros, la escritora busca problematizar lo que Benedito Nunes considera un drama del lenguaje, porque en su obra siempre nos presenta un conflicto entre lo que pretende narrar y la imposibilidad de utilizar palabras para este ejercicio. La autora busca traducir este drama a partir de los vacíos de representación que su texto traduce en forma de silencio y poesía. El artículo pretende desplegar este drama en dos vertientes, siendo la primera la incapacidad de representación por escrito, que nunca debe ser cerrada ni elaborada, sino espontánea, performativa. El segundo se refiere al ejercicio de la alteridad, denunciando la imposibilidad de que la palabra literaria represente la experiencia de los otros. Para ello, la última novela publicada en vida, La hora de la estrella, será el texto utilizado como referencia para el análisis, ya que lleva abiertamente el tema de la representación en la figura de un personaje narrador, un alfabetizado, que intenta, en vano, traducir. la experiencia de los pobres del noreste en las calles de Río de Janeiro.

PALABRA CLAVE: Alteridad, linguaje, silencio.

\section{REFERÊNCIAS}

AGAMBEN, Giorgio. La potencia del pensamiento. Buenos Aires: Adriana Hidalgo, 2005.

. O que resta de Auschwitz: o arquivo e a testemunha. Trad. Selvino J. Assmann. São Paulo: Boitempo, 2008.

BARTHES, Roland. Aula. Trad. Leyla Perrone-Moisés. São Paulo: Cultrix, 1989.

BELCHIOR. Alucinação. Álbum: Alucinação, 1976.

BENJAMIN, Walter. Magia e técnica, arte e política: ensaios sobre literatura e história da cultura. 7.ed. Trad. Sérgio Paulo Rouanet. São Paulo: Brasiliense, 1994. Obras escolhidas v. I.

BLANCHOT, Maurice. O espaço literário. Trad. Álvaro Cabral. Rio de Janeiro: Rocco, 1987.

CURI, Simone. A escritura nômade em Clarice Lispector. Chapecó: Argos, 2001.

DIDI-HUBERMAN, Georges. Sobrevivência dos vaga-lumes. Trad. Vera Casa Nova, Márcia Arbex. Belo Horizonte: Editora UFMG, 2011.

FOUCAULT, Michel. O que é um autor. Trad. Antônio Fernando Cascais e Eduardo e Eduardo Cordeiro. 7. ed. Nova Vega: Lisboa, 2009.

GOTLIB, Nádia. Quando o objeto, cultural, é a mulher. Organon, Instituto de Letras UFRGS, v. 16, n. 16, 1987.

. Macabéa e as mil pontas de uma estrela. In: MOTA, Lourenço Dantas; JUNIOR, Benjamin Abdala (Org.). Personae: grandes personagens da literatura brasileira. São Paulo: Senac, 2001.

HELLER, Alberto Andrés. 2008. John Cage e a poética do silêncio. Tese. (Doutorado em Literatura) - Faculdade de Letras. Universidade Federal de Santa Catarina, Florianópolis. 
LEAL, Juliana Helena Gomes. Literatura e performance: incursões teóricas a partir da escrita literária de Lemebel, Lispector, Prata e Saer. Tese (Doutorado em Literatura Comparada) Faculdade de Letras, Universidade Federal de Minas Gerais, Belo Horizonte, 2012.

LISPECTOR, Clarice. Água viva. Rio de Janeiro: Rocco, 1998a.

. Laços de família. Rio de Janeiro: Rocco, 1998a.

- A bora da estrela. Rio de Janeiro: Rocco, 1999.

LOPES, Luiz Carlos Gonçalves. Formas da alegria: resíduos do trágico em Clarice Lispector. Tese (Doutorado em Literatura Comparada) - Faculdade de Letras, Universidade Federal de Minas Gerais, Belo Horizonte, 2013.

NUNES, Benedito. O drama da linguagem: uma leitura de Clarice Lispector. São Paulo: Ática, 1989.

ORLANDI, Eni. As formas do silêncio. Campinas: Editora da Unicamp, 1995.

PONTIERI, Regina. Clarice Lispector, uma poética do olhar. São Paulo: Ateliê Editorial, 1999.

Recebido em: 22/09/2020.

Aprovado em: 16/11/2020. 